\title{
Does Consumer's Retail Format Choice Decisions Distinguish among 4Cs of Marketing? Evidence from a Research on Jeans wear Retailing
}

\author{
Sudha Vemaraju, Anand Bethapudi
}

\begin{abstract}
PURPOSE: To understand consumer's perceptions on 4 Cs of marketing (Customer solution, Customer Cost, Convenience, and Communication) and their impact on retail format choice decisions in buying jeans. This study found evidence on rarely explored research question i.e. 'Which 4 Cs of Marketing differs among customer's retail format choice decisions in buying jeans.

DESIGN / METHODOLOGY / APPROACH: The data was collected through structured questionnaire by random mall intercept method using simple random sampling technique from 505 customers in Hyderabad, Andhra Pradesh. A valid Discriminant model was developed to test the predictors of 4 Cs of retail attributes across two retail formats (Departmental Stores \&Shopping malls). The data was analyzed through descriptive and inferential statistics.

FINDINGS: Findings indicated that the classification accuracy in analysis, holdout and cross-validated sample is able to correctly classify the 4 Cs of marketing across the two retail formats. Out of the 4Cs of retail marketing attributes studied, 'Convenience and Cost' related attributes, differ significantly across the two retail formats (Departmental Store and Shopping malls), while for 'Communication and Customer solution' no significant impact was found on customer's retail format choice decisions in buying jeans.

RESEARCH IMPLICATIONS: Findings from this study,aid retailers, marketers and manufacturers in understanding customer paradigm shifts in buying patterns across emerging retail formats and direct them in altering $4 \mathrm{Cs}$ of marketing to serve customers better, hence increasing the overall marketing efficiency.
\end{abstract}

LIMITATIONS: Despite efforts taken to represent all sections, it is appropriate to conduct such studies geographical segment-wise to be more accurate, secondly retailers' perceptions were not considered and thirdly unorganized retail was not taken in this context.

ORIGINALITY / VALUE -The researcher could not come across any studies on retail marketing attributes in specific category like jeans wear retail, especially in Indian context and hence this study would add more value in understanding customer's buying behavior across emerging retail formats.

Key Words: 4 c's of marketing, jeans wear relating, Discriminant analysis, retail format choice, Departmental stores, Shopping malls.

Revised Manuscript Received on July 22, 2019

* Correspondence Author

Dr.SudhaVemaraju, M.B.A, M.Phil, Ph.D, PDF (IIT Delhi).

Assistant Professor, GITAM Hyderabad Business School, GITAM University, Hyderabad, India. Email:diwan.sudha@ gmail.com

Dr.AnandBethapudi, B.E.,M.B.A, Ph.D., UGC-NET/JRF

Faculty Member,GITAM Hyderabad Business School, GITAM University,

Hyderabad, India. Email:dr.anandbethapudi@gmail.com

\section{INTRODUCTION}

$\mathrm{C}$ Consumers are exposedto different products, media, markets, cultures, process and are connected to multiple channels which led to retailers to develop Omni channel to provide integrated services across the multiple channels simultaneously and thereby intensified competition in the $21^{\text {st }}$ century. In this current scenario consumers seek increasingly customization of products or services. Hence the retailers need to engage multiple channels through re-inventing and transforming the wheel of marketing to satisfy their customers. The growing competition due to liberalization, privatization, emergence of modern retail formats and the increasing expectations of consumers in view of globalization coupled with flexibility in serving customers, are together defining new rules of game for existing retailers and marketers in India. With the advent of multi-channel retailing and growth of modern retail formats it is important to understand bricks-and-mortar shoppers across various emerging retail formats. India is the fifth-largest global destination in the retail space with $10 \%$ gross domestic product (GDP) projected to be the strongest among G-20 countries and accounts over 8 per cent of the employment. Indian retail market is US\$ 792 billion in 2018 and is expected to reach US $\$ 2,249$ billion by 2028 , growing at a Compound Annual Growth Rate (CAGR) of 11 percent (India retailing, 2019). The modern retailing is expanding on the double pace at $20 \%$, while traditional retail only at $10 \%$ and overall retail market at $12 \%$ per annum. Online retail is likely to be at par with the physical stores at a growth rate of 31 per cent year-on-year to reach US\$ 32.70 billion in 2018. The unorganized retail occupies a major share of $75 \%$, organized retail share almost doubled from $9 \%$ to $18 \%$ and e-commerce retail share will reach 7 per cent of the total retail market by $21 \%$ (IBEF, 2019). As per the estimates of, 'The International Monetary Fund (IMF) and Central Statistics Organization (CSO), India retained to be the fastest growing economy in 2016-17, despite the midnight demonetization shock (IMF WEO, 2017). The urban population of India shall double from the 2001 census data of 290 million people to approximately 590 million people by 2030 A.D. and Young India with 550 million youth under 35 years of age (KSA Technopak, 2010).

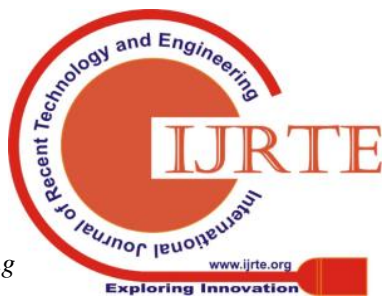


Indian apparel market, the second largest retail category is growing at a CAGR of $13 \%$ and is expected to reach approximately USD 124 billion by 2020 (Euromonitor International: Apparels in India, 2013).

Added to this in 2012, the Government of India eased restrictions on foreign direct investment in multi-brand retail and in 2013, exemption of excise duty on branded apparel further fueled the growth in modern retail among branded apparels alongside with India's eight million traditional retailers (Euromonitor report, 2014).Branded Apparel contributes over $40 \%$ to the Indian apparel market which was INR 1250 billion in 2012 would further grow up to $50 \%$ by 2017 (The Hindu, November 17th, 2013). Western branded apparel, especially Jeanswear is gathering momentum from its conception and its demand remained stronger in India in 2016, accounting for a retail current value growth of $13 \%$ reaching the sales of INR171 billion (Euromonitor International: Jeans in India, 2017).The westernization impact coupled with ongoing trend towards casual attire in work place further fueled the growth and prominence of jeans in India. These facts indicate the huge potential for research in this category. The coexistence of manufacturer and store brands and many global players in this category has intensified competition. There is a huge gap in what customers say and how they exactly behave and hence understanding customers and developing retention strategies became much complex for retailers. Consumer attributes keep varying over time and are often contradictory (Erdem\& Keane, 1996). The consumption goals of consumers differ significantly from time to time and so are their preferences for marketing attributes (Gardial, et al.1994; Oliver, 1999). The consumption goal of a consumer purchasing a particular product may vary based on time thereby resulting in causing variations in attribute importance. Hence from the past studies it can be inferred that the significance attached to each marketing attribute by customers may vary from time to time and across various product categories.

Therefore retailer need to comprehend the consumer shopping behavior for specific categories and align their marketing mix with appropriate marketing efforts to serve customers better in emerging retail formats like Shopping malls (SM) and Departmental Stores (DS) in Indian retail scenario. Hence in order to bridge this gap this study has mainly focused on understanding an important research question 'Does customers' perceptions on 4 Cs of marketing (i.e. Customer Value, Cost, Convenience and Communication)affecttheirretail format choice decisions in Jeanswear retailing?The current paper is presented in five sections. The first section highlights the backdrop and the central idea of this research. The second section reviews relevant literature on $4 \mathrm{Cs}$ of marketing that differentiate among the two retail formats Departmental Stores (DS) and Shopping malls(SM). Methodology of the study was discussed in the third section. Discriminant model and its validation were presented in the fourth section. Managerial implications and directions for further research were offered in the final section.

\section{Which Factors Effect Consumers Retail Format Choice Decisions?}

This section progresses with discussing the literature review relevant to discriminators of consumer's retail format choice decisions, identification of research gaps and based on that formulatedthe hypothesesfor this study.

\section{Retail Formats}

The acceptable range of retail formats is larger for search goods like Jeans wear (Benoit et al. 2019). Researchers (Johansson \&Kask ,2017) opined that store retailers can create strategic advantage when their multi-channel strategy aligns with its business strategy. Further the researchers found that retail format is vital for comprehending the differences in growth and profit. Moreover, the study reveals that to some extent online channels also have positive performance implications for physical store retailers Retail formats considered in this study are 'Shopping malls and Departmental Stores'. Indian malls make up 80.1 million square feet (sq. feet) of space with approximately 15 years of modern retail history.Malls are interconnected walkways withmassive store size, multifaceted shops representing merchandiser'shigh running costs and often offer shallow margins. They provide wide variety, extensive assortment and proffer average prices and mediocre customer service(Eg.Inorbit Mall, Central). The average size of malls is projected at around 3.8 lakh sq. feet, which is expected to raise to 4.7 lakh sq. feet in 2015 and further to INR 6.6 lakh in 2017 (Source: IBEF-Shopping malls to grow in size, numbers report, January 2014).More than 600 malls in India were operational by the end of 2017 and over 30 new shopping malls covering around 14 million sq feet of area are expected to come up by 2020 (Deccan Herald,2019). Departmental store is alienated into numerous departments controlled by specialist retailers and merchandisers. They providewide variety, and best customer services (Eg. Westside, Shoppers Stop).

\section{Discriminators of Consumer's Retail Format Choice Decisions}

Lee and Johnson (1997) found that Consumer's expectations on store attributes differ with retail format type (Lee \& Johnson, 1997).Etzel et al. (2007) from their research found evidence that the four Ps of marketing mix elements influence customers store choice decisions. Carpenter and Moore (2006) from their study foundprice, store atmospherics and product as significant determinants of format choice. He further found evidence that Indian shoppers in their sample were more price and quality conscious than brand. An Indian based research (Patel, 2008) identified perfectionist/high quality conscious, brand conscious, price conscious, impulsiveness/careless, confused by over choice, habitual/brand loyal and variety seeking as significant factors evolving from their research that was carried out across 128 active mall shoppers through mall intercept method. On contrary, researchers (Kau etal. 1984; Uncles et al. 1995; Popkowski et al. 1997) opined that the major issues in the past studies are the fact that the relationship between shopper's attributes and store choice were found to be weak. Despite the rich empirical data related to retail attributes, nevertheless literature review indicates that these attributes differ both in magnitude and direction of the effects for the predictor variables across various studies. Therefore the current research aimed to comprehend the impact of 4 Cs of marketing across two retail formats (SM\& DM) in jeans wear retail. 


\section{Customer Solution (Product) Attributes}

Consumer's choice of a product is based on their preference towards particular attributes that lie in the product (Lanchester, 1996). Further researcher (Uusitalo, 2001) opined that the degree of importance attached to each attribute may varywith the product nature and type. Urbonaviciuset al. (2005) found evidence that product attributes like product quality, assortment of merchandise, variety and product prices influence consumer's format choice decisions. Researchers like Wu \& Delong (2006) found comfort and fit are the most significant product attributes in buying jeans. Researchers (Delong et al., 2002) identifiedcolor and fit as significant product attributesin purchasing jeans. Lennon (1984) found brand name and price influence consumers' decisions in buying jeans.Researchers (Mittal et al., 2001) further suggest thatconsumer's perceptions on product attributes may vary based on product performance and spending goals. Hence the first hypothesis is designed as:

H1: Product attributes have a positive association on consumer's retail format choice decisions.

\section{Cost (Price)Related Attributes}

For store retailers business opportunity lies in consumer's willingness to pay in the store (Shi et al. 2019). For search goods like jeans, retail format's economic factors like price and speed becomes more prominent factors compared to psychological factors like store atmosphere \& customer service (Benoit et al. 2019). Consumers perceived price positively as an important cue in case of quality status and negatively for the same in case of financial sacrifice (Lichtenstein et al. 1990). Lichtenstein et al. (1993) identified price as avital determinant of consumers store choice decisions. Dodds (1995) further added that in case of either a positive or a negative cue, price evolved as an important driver of consumer's purchase decision making process.Researchers (Tuli\&Mookerjee, 2004) concluded that Indian customer'swere quality conscious and price sensitive. Despite price being identified as a significant retail attribute in consumer's store choice decisions, in some instances it was also found to be less prominent (Arnold et al. 1978; Arnold and Tigert, 1983; Walters and Rinne, 1986; Bell et al. 1998). This indicates that the effect of price may be further researched in combination with other retail attributes to comprehend its impact on customer's format choice decisions. Hence our second hypothesis is formulated as: $\mathrm{H} 2$ : Cost related attributes do not impact consumer's retail format choice decisions.

\section{Convenience (Place) Attributes}

Ownbey et al. (1994), suggests location as an important factor for the success of any retail store. Location and parking facilities have significant impact on customer's store patronage behavior, on contrary researchers (Sinha\& Banerjee, 2004) found that parking amenities have negative impact on consumer's store patronage behavior.Further researchers (Calvo-Porral\&Lévy-Mangín, 2018) found that convenience and communication activities do not have a significant influence as pull factors (Calvo-Porral\&Lévy-Mangín, 2018).Based on the literature our third hypothesis is proposed as:

H3: Convenience attributes influence consumer's retail format choice decisions.

\section{Communication (Promotion)Attributes}

Communication strategies aid retailers in improving the profitability and consumers base.Bagozzi et al. (1999) suggests that high quality promotional strategies stimulate consumer's to the store. In-store promotions influence customer's store format choice and patronage behavior (Urbany et al.2000) Coupons were found be effective promotional strategy for durables (Song \& Jeffrey et al. 2008). Further researchers (Venkatesan\& Farris, 2012) foundexposure effects are more influentialthan redemption effects on customers in case of coupons. In this vein, our fourth hypothesis is formulated as:

H4: Communication attributes have a positive impact on consumer's retail format choice decisions.

\section{METHODOLOGY}

In order to accomplish the stated objectives and test the proposed hypotheses we have adopted a four-step procedure for developing the scale for marketing mix attributes. The four stages are briefly explained in this section. Domain Specification: In the first stage we identified the domain for the study (i.e. the core research theme, marketing mix attributes).

Item Pool from Literature: In the second stage we extracted items based on the literature review (i.e) 4 Cs of marketing from pool of literature. The items related to 4 Cs of marketing were selected from past studies (Kotler, 1973; Linquist, 1974; Woodside and Trappey, 1992; Fox et al. 2004; Carpenter \& Moore, 2006) and modified to suit to the current context of the study.

Scale Calibration: In the third stage we purified the scale, adapted and modified based on the qualitative enquiry from three subject matter experts and two retailer managers of each retail format (DS \& SM). Thus we performed the face validity and content validity.

Pilot Test: In this processwe have conducted the pilot test to revise the final instrument for data collection. The purpose of the pilot study was tofilter the key retail attributes and purify the scale. The first pilot study was conducted using structured questionnaire from 150 customers to identify the customers' perceptions on retail attributes.Second pilot test was done on complete questionnaire and was employed on 44 customers for further refinement of the questionnaire. This helped the researcher to gain better insights in time taken for the questionnaire, content clarity (in terms of difficulties faced by customers in comprehending the questionnaire). Some items were deleted in this process to obtain validity and internal consistency for satisfactory results.

Data Collection and Scale Validation: Finally the revised instrument, thus refined was distributed to customers who shop in the retail formats of India from Hyderabad and Secunderabad. The primary data was collected using random mall intercept method. The data was collected from 971 shoppers randomly selected from exit points of stores and located at Hyderabad and Secunderabad, India from ten retail stores (6 Shopping malls\& 4 Departmental stores). Out of which 505 were usable and valid. The response rate is $52 \%$.

The sample $(\mathrm{N}=505)$ had been drawn using Simple random sampling techniquefrom 505 customers through structured questionnaire in Hyderabad and Secunderabad, India.

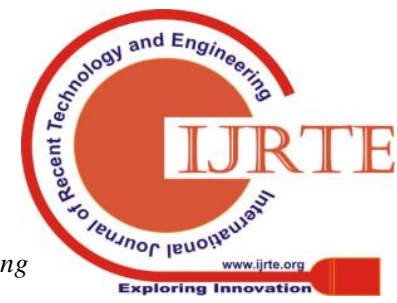


The sample frame is comprised of the customers who basically shop at organized retail outlets in the twin cities. The sample units were the customers of above 18 years and below 60 years, from affluent and middle class and mainly customer's who wear and buy jeans. The underlying principle behind choosing the above sampleis that past studies (Sinha\&Banarjee, 2004) indicated that modern retail formats were by and large visited by customers from affluent class in Indian context. The age group above 18 and below 60 years is chosen because jeans are worn mostly in these age groups. The data collection was done during the period of September-November, 2016.

Scale Validity and Reliability: Reliability of the questionnaire is measured by using Cronbachs' alpha. These statistical tools are used with the help of Predictive Analytics Software (PASW) 20.0 Version. The results also proved that instrument was reliable using 'Cronbach $\alpha$ and found that range of reliability coefficient was greater than 0.7 . The results of Cronbach's $\alpha$ for 4 Cs of marketing are summarized in Table 1.

Table 1: Cronbach's Alpha and Variance Explained for 4 Cs of Marketing Attributes

\begin{tabular}{|c|c|c|c|c|}
\hline $\begin{array}{l}\text { Factor } \\
\text { label }\end{array}$ & Statements & $\begin{array}{l}\text { Fact } \\
\text { or } \\
\text { load } \\
\text { ings }\end{array}$ & $\begin{array}{l}\text { Cronb } \\
\text { ach's } \\
' \alpha \text { ' }\end{array}$ & $\begin{array}{l}\text { Varian } \\
\text { ce } \\
\text { explai } \\
\text { ned }\end{array}$ \\
\hline \multirow{4}{*}{$\begin{array}{l}\text { Conveni } \\
\text { ence } \\
\text { attribut } \\
\text { es }\end{array}$} & $\begin{array}{l}\text { Location of the store } \\
\text { affects my store choice }\end{array}$ & 0.82 & \multirow{4}{*}{0.9} & \multirow{4}{*}{29.659} \\
\hline & $\begin{array}{l}\text { I prefer to buy from the } \\
\text { store that has flexible } \\
\text { shopping hours }\end{array}$ & 0.89 & & \\
\hline & $\begin{array}{l}\text { One stop shopping } \\
\text { convenience affects } \\
\text { my store choice }\end{array}$ & 0.93 & & \\
\hline & $\begin{array}{l}\text { I prefer the store that } \\
\text { provided good parking } \\
\text { amenities }\end{array}$ & 0.89 & & \\
\hline \multirow{6}{*}{$\begin{array}{l}\text { Custome } \\
\text { r } \\
\text { Solution } \\
\text { attribut } \\
\text { es }\end{array}$} & $\begin{array}{l}\text { I prefer the store that } \\
\text { offers variety and } \\
\text { reputed branded jeans. }\end{array}$ & 0.92 & \multirow{6}{*}{0.94} & \multirow{6}{*}{19.135} \\
\hline & $\begin{array}{l}\text { I consider quality in } \\
\text { buying Jeans }\end{array}$ & 0.93 & & \\
\hline & $\begin{array}{l}\text { Color of Jeans } \\
\text { influence my purchase } \\
\text { decisions }\end{array}$ & 0.96 & & \\
\hline & $\begin{array}{l}\text { I consider style in } \\
\text { buying jeans }\end{array}$ & 0.93 & & \\
\hline & $\begin{array}{l}\text { Fit of Jeans influence } \\
\text { my choice }\end{array}$ & 0.96 & & \\
\hline & $\begin{array}{l}\text { Availability/Full } \\
\text { Stocks }\end{array}$ & 0.93 & & \\
\hline \multirow[t]{3}{*}{$\begin{array}{l}\text { Cost } \\
\text { attribut } \\
\text { es }\end{array}$} & $\begin{array}{l}\text { Availability of store } \\
\text { brands reasonable } \\
\text { price influence my } \\
\text { store choice. }\end{array}$ & 0.89 & \multirow{3}{*}{0.92} & \multirow{3}{*}{17.310} \\
\hline & $\begin{array}{l}\text { Value for money } \\
\text { affects my store choice }\end{array}$ & 0.91 & & \\
\hline & $\begin{array}{l}\text { I prefer to buy from the } \\
\text { store where I get } \\
\text { discount offers. }\end{array}$ & 0.94 & & \\
\hline
\end{tabular}

\begin{tabular}{|c|c|c|c|c|}
\hline & $\begin{array}{l}\text { I buy Jeans from the } \\
\text { store that offers } \\
\text { everyday low pricing }\end{array}$ & 0.94 & & \\
\hline \multirow{4}{*}{$\begin{array}{l}\text { Commu } \\
\text { nication } \\
\text { attribut } \\
\text { es }\end{array}$} & $\begin{array}{l}\text { Coupons influence my } \\
\text { store choice decisions. }\end{array}$ & 0.84 & \multirow{4}{*}{0.85} & \multirow{4}{*}{15.631} \\
\hline & $\begin{array}{l}\text { Combo packs stimulate } \\
\text { me to buy more from } \\
\text { the store. }\end{array}$ & 0.86 & & \\
\hline & $\begin{array}{l}\text { I prefer to buy from the } \\
\text { store that offers } \\
\text { seasonal discount to its } \\
\text { members. }\end{array}$ & 0.86 & & \\
\hline & $\begin{array}{l}\text { Gift voucherspersuade } \\
\text { store loyalty. }\end{array}$ & 0.82 & & \\
\hline
\end{tabular}

Source: Primary Data

Measurement of key variables:

The items considered for the study were taken from the existing scales and modified to assess the constructs proposed in the study (i.e. 4 cs of marketing).

Dependent variable:the dependent variable in our study is 'retail format choice' (rfc).the measures for format choice were adopted and developed from yavas (2003) and carpenter and moore (2006). the rfc is a count variable measured by asking the respondents, about which particular store format (coded as departmental store $=1$; shopping malls $=2$ ) is mostly preferred in buying jeans.

Independent Variables:There are four dominant independent variables considered for this study- Customer solution,Cost attributes, Convenience attributes and Communication attributes..

Methods of Analysis: Discriminant analysis was used to analyze the best predictors of $4 \mathrm{Cs}$ of marketing attributes across the two retail formats (DS and SM).

Description of the Sample:Majority of the respondents who participated in this research survey were male $(60.4 \%)$, young people of age group $18-25$ years $(64.6 \%)$ and unmarried/single $(65.9 \%)$. Dominant classes in this research were employed/working $(49.3 \%)$ people, Graduates (43.6\%) and from affluent class who earn monthly income above one lakh Rs $(39.8 \%)$ with family size 4-6 (73.1\%). (Refer Table 2).

Table 2: Demographic Profile of the Respondents

\begin{tabular}{lll}
\hline $\begin{array}{l}\text { Demographic } \\
\text { variables }\end{array}$ & Description & $\%$ \\
\hline \multirow{2}{*}{ Gender } & Male & 60.4 \\
& Female & 39.6 \\
Age & $18-25$ & 64.6 \\
& $26-40$ & 31.7 \\
Marital Status & Married & 3.2 \\
& Unmarried & 0.6 \\
& Employed & 34.1 \\
Occupation & Self-Employed & 49.3 \\
& Services & 6.1
\end{tabular}




\begin{tabular}{lll}
\hline & Students & 32.5 \\
& Home-Maker & 2.0 \\
& Others & 0.4 \\
Education & Under Graduates & 14.9 \\
& Graduates & 43.6 \\
& Post-Graduation \& & 41.6 \\
& Rs. 15000-30000 & 7.1 \\
Income & Rs. 30001-50000 & 15.8 \\
& Rs. 50001-75000 & 7.7 \\
& Rs. 75001-100000 & 29.5 \\
& Above 100000 & 39.8 \\
& Below 3 & 21.6 \\
& 4-6 & 73.1 \\
& Above 6 & 5.3 \\
\hline
\end{tabular}

\section{RESULTS}

The retails formats, 'Departmental Store and Shopping malls' are distinguished along four dimensions using Discriminant analysis. Before starting the analysis we have split the sample into 60-40 between the two sub samples - analysis sample $(60 \%)$ and hold out sample $(40 \%)$. The Discriminant function was tested on the hold out sample to measure the predictive accuracy of the model. This process is suggested by past research studies (Hair et al. 1979; Ramayah et al. 2004, 2006; Morrison et al. 1985) using the two comparison standards Maximum chance, Proportional chance.

The discriminant model is significant (Wilks' Lambda $=0.72$. Approx $\mathrm{F}(21,6444.67)=3.475 \mathrm{P}<0.000)$. The results are presented in Table 1. Among the fourfactors (i.eCustomer solution related attributes, Cost related attributes), convenience related attributes and Cost related attributesare significantly differentiating among the groups (DS and SM). The discriminant loadings of the factors showed that Cost attributes $(0.942)$ is most influential followed by Convenience attributes $(0.495)$ and Communication attributes $(-0.201)$ is the least influential factor discriminating among the two retails formats (DS \& SM). (Refer Table 3).

Table 3: Discriminant Function Output Statistics

\begin{tabular}{|c|c|c|c|c|}
\hline $\begin{array}{l}\text { Independent } \\
\text { Variables }\end{array}$ & $\begin{array}{l}\text { Unstand } \\
\text { ardized }\end{array}$ & $\begin{array}{l}\text { Standa } \\
\text { rdized }\end{array}$ & $\begin{array}{l}\text { Discrimin } \\
\text { ant } \\
\text { Loading } \\
\text { (Rank) }\end{array}$ & $\begin{array}{l}\text { Univa } \\
\text { riate } \\
\text { F-Rat } \\
\quad \text { io }\end{array}$ \\
\hline Convenience & & 0.27 & & 6.464 \\
\hline Attributes & 0.093 & 3 & $0.495(2)$ & $* *$ \\
\hline $\begin{array}{l}\text { solution } \\
\text { Attributes }\end{array}$ & 0.035 & $\begin{array}{c}0.14 \\
4 \\
0.84\end{array}$ & $0.276(3)$ & $\begin{array}{l}2.003 \\
23.38\end{array}$ \\
\hline $\begin{array}{l}\text { Cost Attributes } \\
\text { Communicatio } \\
\text { n Attributes }\end{array}$ & 0.155 & -1.50 & $\begin{array}{c}0.942(1) \\
-0.201 \\
(4)\end{array}$ & 1.068 \\
\hline
\end{tabular}

(Canonical

Correlation $)^{2}$

$* \mathrm{p}<0.05 ; * * \mathrm{p}<0.01$

0.276

Customers who have high preference for Convenience attributes andCost attributes would prefer to shop mostly at Departmental Stores to Shopping malls. Group Centroids reported in Table 2, represent the means of Discriminant function scores for Shopping mallsand Departmental Stores. The Group Centroids for (SM) is -0.202 and 0.406 is(DS).

\section{VALIDATION OF THE MODEL}

For validating the model, we used the method of crossvalidation (split-sample validation).We checked the first assumption, Box's test of equality of covariance matrices and proved significant (Box's $\mathrm{M}=35.305, \mathrm{~F}(10,216444.673)=$ 3.475 , Sig. $=0.000)$, across the two retail formats $($ SM \& DS) (See Table 4).

Table 4: Box's M test results

\begin{tabular}{lcc}
\hline & Test Results & \\
\hline Box's M & & 35.305 \\
F & Approx. & 3.475 \\
& df1 & 10 \\
& df2 & 216444.673 \\
& Sig. & $.000^{* *}$ \\
\hline
\end{tabular}

$* * \mathrm{p}<0.01$

The classification accuracy in analysis sample (See Table 5), reveal that $(62.1 \%)$ of the cases were classified correctly into 'SM' or 'DM' formats. DS were classified with better accuracy $(66.5 \%)$ than SM $(53.3 \%)$.

Table 5: Classification Accuracy of Retail Format Choice Prediction in Analysis Sample

\begin{tabular}{lllll}
\hline \multirow{2}{*}{ Sample } & \multicolumn{3}{l}{ Predicted Group membership } \\
\cline { 3 - 5 } & $\begin{array}{l}\text { Actual } \\
\text { group }\end{array}$ & SM & DS & Total \\
Analysis & SM & 57 & 50 & 107 \\
sample & DS & $(53.3 \%)$ & $(46.7 \%)$ & 215 \\
& & 72 & 143 & \\
& & $(33.5 \%)$ & $(66.5 \%)$ &
\end{tabular}

$62.1 \%$ of selected original grouped cases correctly classified. The classification accuracy in cross validated sample (See Table 6), reveal that $(60.1 \%)$ of the cases were classified correctly into 'SM' or 'DM' formats. DS were classified slightly with better accuracy $(64.2 \%)$ than SM $(50.5 \%)$. The hit ratio of $(60.1 \%)$ for cross validated sample exceeds the maximum (50\%) and proportional chance values (50\%) and also $20 \%$ larger than chance $(60 \%)$.

Table 6: Classification Accuracy of Retail Format Choice Prediction in Cross validated Sample

\begin{tabular}{lllll} 
Sample & \multicolumn{3}{c}{ Predicted Group membership } \\
\cline { 3 - 4 } & $\begin{array}{l}\text { Actual } \\
\text { group }\end{array}$ & SM & DS & Total
\end{tabular}

Group centroid

(DS)

0.406

Group centroid

(SM)

Wilks Lambda 
Does Consumer's Retail Format Choice Decisions Distinguish among 4Cs of Marketing? Evidence from a study on Jeans wear Retailing.

\begin{tabular}{lllll}
\hline Cross & SM & $54(50.5 \%)$ & 53 & 107 \\
validated & DS & $77(35.8 \%)$ & $(49.5 \%)$ & 215 \\
& & & 138 & \\
& & & $(64.2 \%)$ & \\
\hline
\end{tabular}

$60.1 \%$ of selected cross-validated grouped cases are correctly classified.

The classification accuracy in hold-out sample (See Table 7), reveal that $(61.2 \%)$ of the cases were correctly into 'SM' or 'DS' retail store format groups. SMwas classified with better accuracy (64.4\%) than DS retail format group (60.1\%).

Table 7: Classification Accuracy of Retail Format ChoicePrediction in Hold-Out Sample

\begin{tabular}{lllll}
\hline Sample & \multicolumn{3}{c}{ Predicted Group membership } \\
\cline { 3 - 5 } & $\begin{array}{l}\text { Actual } \\
\text { group }\end{array}$ & SM & DS & Total \\
\hline Holdout & SM & 29 & 16 & 45 \\
sample & DS & $(64.4 \%)$ & $(35.6 \%)$ & 138 \\
& & 55 & 83 & \\
& & $(39.9 \%)$ & $(60.1 \%)$ & \\
\hline
\end{tabular}

$61.2 \%$ of unselected original grouped cases correctly classified.

The hit ratio of $(61.2 \%)$ for hold-out sample exceeds the maximum $(50 \%)$ and proportional chance values $(50 \%)$ and also $20 \%$ larger than chance $(60 \%)$. (See Table 8$)$.

Table 8: Comparison of Goodness of Fitness Indices

\begin{tabular}{lcr}
\hline Measure & Value & \% correctly classified \\
\hline Maximum chance & 0.50 & 62.1 \\
Proportional chance & 0.50 & \\
Comparison with Morrison & & \\
et al. (1985) 1.20 & & \\
times higher than chance & & 0.60
\end{tabular}

$* * \mathrm{p}<0.01$

Hence in all the three cases (Analysis sample, cross validated sample and hold-out sample) the levels of classification accuracy are significantly higher than the threshold values, indicating that predictive power of the model is good. However the predictive power of the model is just $28 \%$ which indicates a weak discriminating power among the two retail formats. But the results of the study is consistent with the past studies on retail attributes (Kau\& Ehrenberg, 1984; Uncles \& Hammond, 1995; Popkowski et al. 1997) that supported our results that the problem in most of the existing studies on store choice is that the relationship between store choice and the retail attributes are very weak. The summary of hypotheses tests is shown in Table 8. The results for Customer solutionattributes are inconsistent with past studies (Urbonaviciuset al. 2005; Lanchester, 1996). The results for Cost attributes are consistent with past studies (Lichtenstein et al. (1993; Doods, 1995) but contradicting with the studies (Arnold \&Tigert, 1983; Walters \&Rinne, 1986). The results for Convenience attributes are consistent with (Sinha and Banerjee, 2004; Bearden,1977). The results for Communication are contradicting with past studies (Bagozzi et al.1999; Urbany et al. 2000).
Table 8: Summary of Hypotheses test

\begin{tabular}{llr} 
S.no & Hypotheses & Result \\
\hline H1 & Customer solutionis positively & Not
\end{tabular}
associated with consumer's retail format Supported

H2 Cost related attributes do not have a significant impact on consumer's retail format choice decisions.

H3 Convenience attributes are positively influencing consumer's retail format

H4 Communication attributes have a positive impact on consumer's retail format choice decisions.

\section{V.DISCUSSION}

In the midst of the heightened level of new-fangled competition due to the coexistence of manufacturer and store brands, social media as an emerging retail format choice in today's scenario posed an important challenge called customer retentionacross emerging retail formats. The key objectiveof this study was to predictthe factors that discriminate among the two retail formats (Departmental Stores \&Shopping malls). Findings reveal that among the $4 \mathrm{Cs}$ of marketing attributes (Customer solution, Cost, Convenience and Communication) only two attributes-Convenience (Place) and Cost (Price) discriminated among the two retail formats.Customer solution(Product) attributes and Communication (Promotion) does not significantly affect customers' retail format choice decisions in buying jeans. In other way, we can understand that irrespective of any retail format choice customer's perceptions on product related attributes and promotion remain same. Overall it can be inferred that though consumer's perception on 4Cs of marketing are discriminating among the two retail formats (Departmental Store \&Shopping malls), but the discrimination is not much ( Only $27 \%$ ) in buying jeans. The reason may be firstly due to a specific category like jeans considered for study and secondly modern retail formats are still emerging in place like Hyderabad, India. However the results might differ if similar study may be carried out in wider categories like Apparels, Food and Grocery considering different retail formats and vary across various geographies.

From the current study the evolved implications for retailers and marketing managers for creating aneffective marketing strategy forjeans wear customer's are- Firstly as convenience and cost attributes are important predictors in customers' store format choice decisions, retailers should emphasize more on redesigning marketing strategies to serveand retain the price sensitive customer's throughEDLP (Everyday Low Pricing). Retailers must enhance the overall physical store experience, rather than just a store to transact and also providing integrated services seamlessly through Omni channels. As promotion and product attributes are not discriminating among the two retail formats (Departments Store \&Shopping malls), promoting apparel brands using various social media platforms locally. 
Digital experience like three-dimensional automatic made-to measure scheme that provide virtual experience are the powerful methods of reaching potential customers', especially youth who are the target consumers for jeans. Fast fashion merchandising may also be used to position branded jeansand thereby enhance brand loyalty. Services like 'No question exchange policy' and 'Alteration services'may also be a way to go.

\section{CONCLUSION}

Hence, this study would enable retailers to understand customers perceptions' in creating a flexible marketing environment through redesigning the retail attributes and marketing communication to retain and attract potential customers to achieve sustainable competitive advantage in shopping for jeans. Therefore, given the dearth of published scholarly literature linking customers' perceptions on 4Cs of marketing attributes in specific to Jeans wear retail and the formats studied in retail environment, this study may perhapsendow as a departure point for further research in this arena and also can be replicated across various retail categories, geographies and emerging formats.

\section{REFERENCES}

1. Arnold, Stephen J., S. Ma, and Douglas J. Tigert., "A comparative analysis of determinant attributes in retail store selection", Advances in consumer research, Vol. 5, 1978, pp.663-667.

2. Arnold, Stephen J., Tae H. Oum, and Douglas J. Tigert., "Determinant attributes in retail patronage: Seasonal, temporal, regional and international comparisons", Journal of Marketing Research , Vol.20,

3. Bearden, W.O., "Determinant attributes of store patronage: Downtown versus outlying shopping centers", Journal of Retailing, Vol.53, No. 2, 1977, pp.15-22.

4. Bell, D.R., Lattin, J.M. Shopping behavior and consumer preference for store price format: why large shoppers prefer EDLP", Marketing Science, Vol.17, No.1, 1998, pp.149-157.

5. Bellenger, D.N., Korgaonkar, P.K., "Profiling the recreational shopper," Journal of Retailing, Vol.56, No. 3, 1980, pp.77-91.

6. Bellizi , Joseph A. Bellizzi, Harry F. Kruckeberg, John R. Hamilton, Warren S. Martin. Consumer Perceptions of National, Private, and Generic Brands. Journal of Retailing, 57, 1981, pp. 56-70 (Winter)

7. Benoit, S., Evanschitzky, H., \& Teller, C. 2019. Retail Format Selection in on-The-Go Shopping Situations.Journal of Business Research, 100, 268-278.

8. Calvo-Porral, C., \&Lévy-Mangín, J.-P. 2018. Pull Factors of the Shopping Malls: An Empirical Study.International Journal of Retail and Distribution Management, 46(2), 110-124.

9. Carpenter, J., Moore, M. Consumer demographics, store attributes, and retail format choice in the US dynamics in food and grocery retailing in India", Vision-The journal of Business Perspective, Vol.11, 2006, 452.

10. Churchill, G., 'A paradigm for developing better measures of marketing constructs', Journal of Marketing Research, Vol. 16, No. 1, 1979, pp. 64-73.

11. De Wulf, Kristof, et al. "Consumer perceptions of store brands versus national brands." Journal of Consumer Marketing 22.4 ,2005, 223-232.

12. DeLong, M., LaBat, K., Nelson, N., Koh, A. and Kim Y., "Global products, global markets: Jeans in Korea and the United States". Clothing and Textiles Research Journal, Vol.20, No.4, 2002, pp.238-245.

13. Dodds, B, "Market cues affect on consumers product evaluations", Journal of Marketing Theory and Practice, Vol. 3, 1995, pp 50-63.

14. Dodds, William B., Kent B. Monroe, and DhruvGrewal. "Effects of evaluations." Journal of marketing research (1991): 307-319.

15. Fox, E., Montgomery, A., Lodish. L., "Consumer Shopping and spending across retail formats", Journal of grocery market", International Journal of Retail \& Distribution Management, Vol. 34, No.6, 2006, pp.434-India”, IMI disha, Vol. 1, No.2, 2008, PP.35-44. Issue I, Pp.80-88. May, 1983, pp 149-57. price, brand, and store information on buyers' product

16. Fox, E.W., Montgomery, A.L., and Lodish, L.M. Consumer Shopping and Spending Across Retail Formats. Journal of Business, Vol.77, No.2, 2004,pp. S25-S60.

17. Gardial, Sarah Fisher, D. Scott Clemons, Robert B. Woodruff, David W. Schumann, and Mary Jane Burns., "Comparing Consumers' Recall of Pre-purchase and Post-purchase Product Evaluation Experiences." Journal of Consumer Research, Vol. 20 (March), 1994, pp. 548-560.

18. http://economictimes.indiatimes.com/industry/services/retail/india-lik ely to ease restrictions for foreign online retailers, 4th June, 2014. Accessed on August 10th, 2014.

19. http://ww.ibef.org/research/reports/shoppingmalls-to-grow-in-size-numbers-in-2014-report. Accessed on March 2014.

20. http://www.bcgindia.com/documents/file181823.pdf, accessed on September 30th, 2015.

21. http://www.eiu.com/industry/consumer-goods/asia/india. Accessed on August 14th, 2014

22. http://www.euromonitor.com/jeans-in-india/report, April 2017 Accessed on May 10 $0^{\text {th }}, 2017$.

23. http://www.ibef.org/industry/retail.aspx report, May 2014. Accessed on July 6th, 2014

24. http://www.ibef.org/industry/retail-india.aspx, accessed on October 2nd, 2015.

25. http://www.indiaretailing.com/7/90/12/10692/Growth-and-Developm ent-of-Malls-The-Indian-Scenario-. Accessed on May 10th, 2014.

26. http://www.indiaretailing.com/7/90/12/10692/Growth-and-Developm ent-of-Malls-The-Indian-Scenario-, Accessed on May 12th, 2014.

27. http://www.portal.euromonitor.com/portal/analysis/blogindex/Appare 1s and Footwear in India, October 2014. Accessed on August 2014.

28. http://www.portal.euromonitor.com/portal/analysis/tab/, The new face of private labeling: Global market trends to 2018, August, 2014. Accessed on June 2015.

29. http://www.portal.euromonitor.com/portal/analysis/tab/Jeans in India August 2013. Accessed on May 2014.

30. http://www.portal.euromonitor.com/portal/analysis/tab/retailing in India, March 2014. Accessed on July 2014.

31. http://www.rai.net.in/ViewSinglePublicationDetails. Accessed on June 19th, 2014

32. https://www.deccanherald.com/business/economy-business/rise-andgrowth-indian-malls. Accessed on October $10^{\text {th }}, 2019$.

33. https://www.ibef.org/industry/retail-india. Accessed on May 10th 2017.

34. https://www.indiaretailing.com/2019/08/16/fashion/indian-denim-we ar-market. Accessed on October $10^{\text {th }}, 2019$.

35. IMF WEO, 2017 Forecasts as cited in http://www.livemint.com/ Accessed on May $12^{\text {th }}, 2017$.

36. Jayasankaraprasad, Ch. \&Raghunatha Reddy D, "A study on role of demographic and psychographic Journal of Marketing, Vol. 39, No. 7/8, 2005, pp.821-837.

37. Johansson, T., \&Kask, J. 2017. Configurations of Business Strategy and Marketing Channels for E-Commerce and Traditional Retail Formats: A Qualitative Comparison Analysis (QCA) in Sporting Goods Retailing. Journal of Retailing and Consumer Services, 34, 326-333.

38. Kahn, B. E., Schmittlein, D. C., "Shopping Trip Behavior: An Empirical Investigation", Marketing Letters, 1989

39. Kau, Ah Keng., A. S. C. Ehrenberg, "Patterns of Store Choice", Journal of Marketing Research, Vol. 21, 1984, pp. 399-409.

40. Kotler. P., "Atmospherics as a marketing tool", Journal of Retailing, Vol. 49, 1973, pp.48-64.

41. KSA Technopak retail report- 2010 e = expected

42. LaBat, L. \& DeLong, R., "Body cathexis and satisfaction with fit of apparel", Clothing and Textiles Research Journal, Vol.8, No.2, 1990, pp 43-48.

43. Lancaster,K.J ,A new approach to consumer theory", The Journal of Political Economic, Vol.74, 1971, pp.132-157.

44. Lee, J.E., "Consumer expectation for service at apparel retail outlets", Journal of Family and Consumer Sciences, Vol. 89, 1997, pp.26-30.

45. Lichtenstein, D., Ridgway N. and Netemeyer, R. G. "Price perceptions and Consumer shopping Behavior: A field Study", Journal of Marketing Research, Vol. 30, No.2, 1993, pp. 234-215. 
46. Lichtenstein, D.R., Netemeyer, R.G., Burton S., "Distinguishing coupon proneness from value consciousness: an acquisition-transaction utility theory perspective", Journal of Marketing, Vol. 54, No. 3, 1990, pp.54-67.

47. McKinsey Global International Report, 2007

48. Miranda, M. J., Konya, L., \&Havrilla, I., "Shoppers Satisfaction Levels Are Not The Only Key to Store Loyalty", Journal of Marketing Intelligence \& Planning, Vol. 40(1/2), 2005, pp. 310-322.

49. Mitchell, V and Harris, G., "The importance of consumers' perceived risk in retail strategy", European No.4, 2007, pp.21-30.

50. Oliver, Richard, L. , 'Whence Consumer Loyalty', Journal of Marketing, Vol. 63(Special issue), 1999, pp. 33-44.

51. Ownbey, K. L., Davis, K., Sundel, H. H., "The effect of location variables on the gross. rents of the neighborhood shopping centers", Journal of Real Estate Research, Vol.9, No.4, 1994, pp. 111-121.

52. Pan, Y. Zinkhan, G.M.,"Determinants of retail patronage: A meta-analytical perspective", Journal of Retailing, Vol. 82, No.3, 2006, pp. 229-244

53. Pan, Y., Zinkhan, G.M., "Determinants of retail patronage: a meta-analytical perspective", Journal of Retailing, Vol. 82 No.3, 2006, pp.229-43.

54. PopkowskiLeszczyc, Peter, and Harry Timmermans. "Store-switching behavior." Marketing Letters 8.2 (1997): 193-204.

55. RamachandraAryasri, A. \& Ch. Jayasankaraprasad, "A study on role of consumerism in modern retailing in Retail \& Distribution management, Vol. 32, No.10, 2004, pp. 482-494.

56. Shi, M., Zhou, J., \& Jiang, Z. 2019. Consumer Heterogeneity and Online Vs. Offline Retail Spatial Competition.Frontiers of Business Research in China, 13(1), 1-19.

57. Sinha, P. K. \&Arindam Banerjee, "Store choice behaviour in an evolving market", International Journal of 2005-07-04, IIMA. Vol.1, No.1, 1989, pp. 55-69.

58. Sinha, P. K., Mathew, E., Kansal, A., "Format choice of food and grocery retailer", working paper No.SuGyaan (ISSN- 0975-4032) Management Journal of Siva Sivani Institute of Management, Vol. III, trips.

59. Song-Zan Chiou-Wei and J. Jeffrey Inman., "Do Shoppers like Electronic Coupons? A Panel Data Analysis", Journal of Retailing, Vol.84, No.3, 2008, pp. 297-307.

60. T Erdem, M.P Keane., "Decision-making under uncertainty: Capturing dynamic brand choice processes in turbulent consumer goods markets", Marketing science, Vol.15, No.1, 1996, pp. 1-20.

61. Tigert, Douglas J. "Pushing the hot buttons for a successful retailing strategy."Patronage behavior and retail management (1983): 89-113.

62. Uncles, Mark, Andrew Ehrenberg, and Kathy Hammond. "Patterns of buyer behavior: Regularities, models, and extensions." Marketing Science14.3_supplement (1995): G71-G78.

63. Urbany, Joel E., Peter R. Dickson, and Alan G. Sawyer. "Insights into cross-and within-store price search: retailer estimates vs. consumer self-reports." Journal of Retailing 76.2 (2000): 243-258.

64. Urbonavicius, S., and Ivanauskas, R. , "Evaluation of multiple retailers' market positions on the basis of image attributes measurement", Journal of Business Economics and Management Vol.7, No.4, 2005 , pp.196-206.

65. Uusitalo, O., "Consumer Perception of Grocery Retail Formats and Brands", International Journal of Retail and Distribution Management, Vol.29, No.5, 2001 , pp. 214-226.

66. V. Mittal, P. Kumar, and M. Tsiros, "Attribute-Level Performance and Customer Satisfaction over Time: Evidence from two field studies", Journal ofServicesMarketing, Vol.15, No.5, 1994, pp. 343-356.

67. Van Kenhove, P., De Wulf, K. and Wan Waterschoot, W., "The impact of task definition on store-attribute saliences and store choice", Journal of Retailing, Vol. 75, No. 1, 1999, pp. 125-37.

68. Venkatesan, Rajkumar and Paul Farris, "Coupons are Not Just for from Retailer-Customized Coupon Campaigns,” Journal of Marketing, Vol.76, No.1,2012, pp. 76-94.

69. Walters, R. G., and Rinne, H. J., "An Empirical Investigation into the Impact of Price Promotions on Retail Store Performance", Journal of Retailing, Vol.62, 1986, pp. 237-266.

70. Wu, J. and DeLong, M. . 'Chinese perceptions on Western-branded denim jeans: A Shanghai case study'. Journal of Fashion Marketing and Management, Vol.10, No.2, 2006, pp. 238-250.

71. www.thehindu.com/business/industry/branded-apparels-poised-to-gro wl, November, 2013. Accessed on February 2014

72. Zhang, Z., Li. Y., Gong, C. and Wu, H., "Casual wear product attributes: A Chinese consumers' perspective”. Journal of FashionMarketing and Management, Vol. 6, No.1, 2002, pp. 53-62.

\section{AUTHORS PROFILE}

Dr.SudhaVemaraju, M.B.A, M.Phil, Ph.D, PDF (IIT Delhi). Assistant Professor, GITAM Hyderabad Business School, GITAM University, Hyderabad, India. Email:diwan.sudha@gmail.com

Dr.AnandBethapudi, B.E.,M.B.A, Ph.D., UGC-NET/JRF

Faculty Member,GITAM Hyderabad Business School, GITAM University, Hyderabad, India. Email:dr.anandbethapudi@gmail.com 